\title{
Research into Personalized Information Services of University and College Libraries
}

\author{
Maoli Xu \\ library, \\ JiLin Agricultural University, \\ Changchun, China \\ Email: 473352805@qq.com
}

\begin{abstract}
The individual information service manifested service the idea of take the user as the center, the development which service for the library information brings the vitality. The university library should use oneself in aspect the service resources, service technology superiority, expand the individual information service connotation, constantly promotes the library service ability. This article studied the university library individual information service connotation, the basic feature as well as the developing strategy.
\end{abstract}

Key words-individual information service; university library; information service studies

\section{INTRODUCTION}

With the rapid development of computer science and internet communication technology, the expansion of information makes information resources in disarray,and user differences in the use of information resources, which have exacerbated the contradiction between the user information needs and the disorder of information resources distribution。 User information needs change makes the library information service also will change。 Traditional information service model has been unable to meet the user's individual information needs in the university library o University library take an important task to provide users with personalized information services to meet the information needs 。

\section{CONNOTATION OF PERSONALIZED INFORMATION SERVICES OF UNIVERSITY AND COLLEGE LIBRARIES}

Libraries are an important support for the scientific research and talent cultivation of schools. Teachers and students can make them serve their knowledge learning, teaching practices and scientific research. University and college teachers often have dual tasks. One is teaching and the other is scientific research. To fulfil both tasks, a systematic and specialized information network is necessary to provide the theoretical support for their scientific research projects. Libraries can provide the latest subject dynamic information to support the information reserve during their research process. To students, libraries can make up for the gap of their in-class learning through voluminous references, broaden their range of knowledge and get them prepared for the future career self-cultivation ${ }^{[1]}$.
The personalized information services of university and college libraries refer to the establishment of the individual collection through the tools provided by the network system to meet users' individual learning and scientific research demands. At the same time, the system can analyze the basic information of users, including their interest, hobbies, majors or research directions, to regularly and automatically recommend desired information for users.

\section{BASIC CHARACTERISTICS OF PERSONALIZED INFORMATION SERVICES OF UNIVERSITY AND COLLEGE LIBRARIES \\ A. More clarified and targeted service purposes}

The service objects of university and college libraries are teaches and students in school. The specificity of the service objects makes the services more targeted and clarified. The service objects can be divided into several types according to their different identities and levels. Different service objects lead to different demands. To meet different demands, services should be differentiated. Therefore, library service personnel should vary their services according to the service objects.

\section{B. More professional services}

University and college teachers are different from each other in terms of their specialty, academic background and purposes of going to libraries. Library service personnel should provide knowledge related to their specialty. Professionalism of university and college library services is more obviously reflected as personalized information services $^{[2]}$

\section{Diversified service approaches}

Traditional libraries mainly provide the print information for users. Under the network environment, the resource forms are diversified. Apart from print resources, there are electronic documents, which can achieve real-time interaction through QQ, MSN, Email and other ways by users or service personnel. 


\section{DEVELOPMENT COUNTERMEASURES FOR NETWORK-BASED PERSONALIZED INFORMATION SERVICES OF UNIVERSITY AND COLLEGE LIBRARIES}

\section{A. Improve the personalized information service management mechanism}

Since Chinese libraries lack a macro regulation mechanism, China Academic Library and Information System (CALIS) is established to coordinate and development libraries to achieve information sharing. To enhance the cooperation between CALIS and various member libraries can help improve the service level of higher education and give full play to its social and economic benefits. However, to sharpen the service awareness and management methods cannot meet libraries' demands for the improvement of the service quality. Cross-department cooperation, structural adjustment and unification of evaluation system are indispensable. To master users' information demands, to track and evaluate service quality, emphasize on feedback of users' satisfaction degree and stimulating service personnel's initiative can provide users with all-around and high-quality personalized information services. To development personalized information services of libraries is of vital importance to the improvement of libraries' personalized information service mechanism $^{[3]}$.

\section{B. Enhance the information resource construction}

Strengthen information resource content construction.It is necessary to build professional navigational database and specialized database. To respond to the high-speed inflation and the out-of-order network information resources, libraries should collect, assort and summarize the network information resources according to different fields, highlight the professional navigation of subjects and establish professional navigation links so as to meet users' teaching and scientific research purpose. In terms of information resource construction, libraries should conduct a careful survey of databases both at home and abroad, and build specialized databases according to the specialty arrangement, focus of scientific research, users' information demands and their own characteristics. Moreover, the full-length digitalized resources collection can be built. Databases like CNKI, Wanfang Data and CQVIP are familiar to scholars. The full utilization of them can provide sound bases for the learning and scientific research of teachers and students. At present, various university and college libraries have provided the full-length reading and download functions. However, these databases have limits for users' reading and downloading, which is not beneficial for the realization of personalized services.

Reinforce the organization and integration of information resources.Resource integration and service integration are a major part of information resource integration. Resource integration refers to the integrated information system formed by assorting the current information resources. Service integration should build the personalized information base. The information base includes users' basic information, such as users' feedback of services. Compared with the traditional information services, personalized information services have new requirements for the organization of information resources. First, the content should be targeted, clear, open and flexible. Second, the navigation system should feature a detailed and reasonable classification, a friendly user interface, a strong information navigation system and information evaluation capability, and a cross-platform seamless connection of information resource content Libraries should assort the discrete electronic resources, and build a professional and all-around navigation database featuring a friendly interface and powerful functions. The information resources with a high use rate should be downloaded and classified for the reference of users ${ }^{[4]}$.

\section{Change the service concept and improve the qualities of the service personnel}

The humanistic service concept of "putting users in the first place" should be built. Such a service concept can contribute to the positive and effective implementation of the libraries' personalized information services. It means to meet users' demands should be the priority and the fundamental goal of library services. Libraries are to serve users and bring utmost convenience to them. The traditional service model has been changed by the personalized information service. The service is a one-to-one and point-to-point service, aiming at providing literature resources featuring knowledge units. Thus, it has a higher requirement of information accuracy. Rich knowledge and moral cultivation are basic qualities of service personnel required by the professionalism and academic nature of the personalized services. In order to meet users' different demands, service personnel should have strong information analysis capability and high language competence, which can help them better answer users' questions. Service personnel should broaden the range of their knowledge and strengthen their study, especially knowledge related to library intelligence. To proficiently master information skills can help users analyze and summarize information, and master various information resources and retrieval methods. Only with these qualities and abilities, service personnel can improve their service quality and provide users with personalized information services.

\section{Deepen research into users' demands and relevant training}

Knowledge lectures should be held regularly and irregularly to immediately convey new knowledge, new techniques and new resources to users so as to attract more users. Libraries should help new users learn information acquisition methods and basic retrieval tools and techniques; 
provide in-depth re-education opportunities for old users and enhance their ability to acquire information. Besides, documents related to knowledge lectures can be uploaded on the library networks for the convenience of learning and reference. Attention should be paid to users' service feedback guidance. Users' feedback is an important approach for libraries to improve their personalized information services. The feedback includes whether the information provided is correct, comprehensive and timely; whether users are familiar with service methods and content and system operations. Library service personnel should find out problems based on users' feedback so as to adjust their personalized information services ${ }^{[5]}$.

\section{E. Improve the personalized information service system construction}

Libraries should conduct the personalized information service system construction to equip it with rich resources, functions and services. The system interface should be designed to be concise, unsophisticated and clear, and allow users to conduct personalized customization. In other words, the system should be able to be automatically integrated with the other resource systems. This can not only save users' time, but also alleviate users' use burden and protect users' privacy. Measures to improve the personalized information services include: the establishment of a professional navigation system, the building of an effective information space, the systematic organization of relevant information resources and the creation of a favorable retrieval interface. Through information customization and recommendation, system can provide users with options. Users can also choose and manage information to achieve the interaction function. Any problems encountered by users while using the resource system should be immediately solved so as to improve service quality.

\section{V.CONCLUSION}

To sum up, under the network environment, university and college libraries will face many problems during the construction process of the personalized information services. To respond to these problems, university and college libraries should improve their personalized service management mechanism, enhance information resource construction, strengthen the personalized information service system construction and deepen research into users' demands and relevant training. While changing the service concept, library service personnel should pay attention to the improvement of their qualities and service quality. Only in this way can the personalized information services of university and college libraries keep improving.

\section{ACKNOWLEDGMENT}

This paper is the periodical achievement of the research project of "In-depth integration and recommendation of library resources under the big data background” (Project No.: 2015019) in 2015 of CALIS China Agriculture Literature and Information Center.

\section{REFERENCES}

[1] Yan Jingyi, Xia Yanshi. Medical College Library proved individualized information servicefor the society Based on Electronic Environment[J].Electronic Test,2014(20):123-125.

[2] ZhongYuhuo. Research on the Personalized Information Recommending Service of DigitalLibrary in Higher Vocational College[J].Agriculture Network Information,2014(12):109-111.

[3] Xie Zhen, Yang Jiulong. Study on My Library Personalized Information Service Based on SNS[J].Library Tribune,2014(4):70-74.

[4] Yin Zhiqing. On Web2.0-based Individualized Information Service of University Libraty[J].Journal of Wuhan Institute of Shipbuilding Technology,2013(3):55-57.

[5] Cong Lin. Research on University Library's Personalized Information Service[J].Sci-Tech Information Development\& Economy,2013(21):28-30. 